\title{
COMPETITIVENESS POSITION IDENTIFICATION OF INDIHOME USING SERVICE QUALITY FOR ISP DIMENSIONS AND IPCA METHOD
}

\author{
Sari Wulandari*), Agus Achmad Suhendra*), Putra Fajar Alam**) \\ ${ }^{*}$ Industrial Engineering Department, School of Industrial and System Engineering \\ Jl. Telekomunikasi No.1, Telkom University, Terusan Buah Batu, Bandung 40257, Indonesia \\ ${ }^{* *}$ Information System Department, School of Industrial and System Engineering \\ Jl. Telekomunikasi No.1, Telkom University, Terusan Buah Batu, Bandung 40257, Indonesia
}

\begin{abstract}
Two major Internet Service Provider (ISP) players, namely Indihome and Firstmedia, experienced a significant increase in traffic. On the other hand, there has been a decline in service quality, due to a spike in the volume of internet usage. The objectives of this study are (1) to identify the strengths and weaknesses of Indihome's fixed broadband services using IPA, (2) to determine the competitive position of Indihome relative to First Media based on Importance Performance Competitor Analysis (IPCA) mapping, (3) to compare the results of evaluating the quality of IPA and IPCA services. The results showed that Indihome has weaknesses in all indicators of Network Quality, 2 indicators of Customer Service \& Technical Support (CT6- the ability of CS to resolve complaints, CT3 - CS has product knowledge), and 1 indicator of Security \& Privacy (SP1 - security of customer personal data) while the advantages are in 2 indicators of Customer Service \& Technical Support (CT2 - completeness of technician installation tools, CT5 - speed of complaint handling), 2 indicators of Security \& Privacy (SP2 - transaction data security, SP3 - transaction system security), 1 Information Quality \& Website Support indicator (IW4 - channel availability diverse communications), and 1 indicator of Customer Service \& Technical Support (CT1 - technician uniform attributes). In addition, the IPCA matrix shows that Indihome's Competitive Position is on the CT2, CT5, IW2 indicators - various payment methods, IW5 - up-to-date information, SP2, and SP3. Based on the comparison of IPA and IPCA data, it is known that there are indicators that perform well when assessed internally but that performance is not better enough when compared to competitors, namely CT1 and IW4.
\end{abstract}

Keywords: internet service provider, service quality, importance performance competitor analysis, competitive position

\begin{abstract}
Abstrak: Dua pemain besar Internet Service Provider (ISP) yaitu Indihome dan Firstmedia mengalami peningkatan peningkatan traffic secara signifikan. Di sisi lain, terjadi penurunan kualitas layanan yang diakibatkan adanya lonjakan volume penggunaan internet. Tujuan penelitian ini adalah (1) mengidentifikasi kelebihan dan kelemahan layanan fixed broadband Indihome dengan menggunakan Importance Performance Analysis (IPA), (2) menentukan competitive position Indihome relatif terhadap First Media berdasarkan pemetaan Importance Performance Competitor Analysis (IPCA), (3) membandingkan hasil evaluasi kualitas layanan IPA dan IPCA. Hasil penelitian menunjukan bahwa Indihome memiliki kelemahan pada semua indikator Network Quality, 2 indikator Customer Service \& Technical Support (CT6 - kemampuan kemampuan CS dalam menyelesaikan komplain, CT3 - CS memiliki pengetahuan tentang produk), dan 1 indikator Security \& Privacy (SP1 - keamanan data personal customer) sedangkan kelebihannya ada pada 2 indikator Customer Service \& Technical Support (CT2 - kelengkapan alat instalasi teknisi, CT5 kecepatan penanganan komplain), 2 indikator Security \& Privacy (SP2 - keamanan data transaksi, SP3 - keamanan sistem transaksi), 1 indikator Information Quality \& Website Support (IW4 ketersediaan saluran komunikasi yang beragam), dan 1 indikator Customer Service \& Technical Support (CT1 - kelengkatan atribut seragam teknisi). Selain itu, matriks IPCA menunjukan bahwa Competitive Position Indihome ada pada indikator CT2, CT5, IW2 - variasi metode pembayaran, IW5 - informasi yang up-to-date, SP2 dan SP3. Berdasarkan perbandingan data IPA dan IPCA diketahui bahwa terdapat indikator berkinerja baik jika dinilai secara internal namun kinerja tersebut tidak cukup lebih baik jika dibandingkan dengan competitor yaitu CTI dan IW4.
\end{abstract}

Kata kunci: internet service provider, kualitas layanan, importance performance competitor analysis, competitive position

${ }^{1}$ Corresponding author:

Email: sariwulandariit@telkomuniversity.ac.id 


\section{INTRODUCTIONS}

The Corona pandemic has caused changes in lifestyle in every lifeline of Indonesian people. Indonesian people now rely heavily on digital technology services (Dianawanti, 2020). Therefore, internet service or Internet Service Providers has become one of the main commodities so that Indonesians can use digital services optimally. The Minister of Communication and Information stated that internet penetration in Indonesia has reached 172 million of the total 270 million population. The government hopes that internet service operators can maintain their internet service capacity properly (Kamaliah, 2020). During the Corona pandemic, internet use in West Java increased significantly. The main factor in the increasing activity of internet use is the existence of a government policy to stay at home and carry out work from home activities.

The Executive Vice President of Telkom Regional III of West Jawa, M Khamdan stated that when the spread of Covid-19 began to be discussed, the use of Indihome products from January to March increased by $20 \%$. This increase continued until mid-March to April where the policy for work and school activities was carried out from home with an increase in internet use of up to $30 \%$ (Anggoro, 2020). In addition, during WFH, the demand for new Indihome installations in March was higher than the previous month by $30-40 \%(C N N, 2020)$. The same thing happened to First Media's internet service. There was a significant increase in First Media service traffic, namely around $47 \%$, followed by an increase in the number of subscribers by $40 \%$ from mid-March to May 2020. However, the increase in internet usage during the Corona pandemic in Indonesia was not followed by good network performance and quality. Based on data from Ookla which is a global internet speed research company, it is known that during the LSSR (Large-Scale Social Restriction) period from March to June 2020 there was a decline in download speeds in Indonesia. The details related to the data are as follows (Hamdani, 2020):

- The average internet download speed fell to 19.67 Mbps from March 16 - June 82020 where previously the average speed reached $20.57 \mathrm{Mbps}$ from December 16, 2019 - March 9, 2020.

- This decrease in speed was followed by an increase in the volume of cable internet usage to $24.69 \%$ on March 16 - June 8, 2020, where previously the average volume on December 16, 2019 - March 9 2020 reached $-3.5 \%$.
The need for a large internet data connection especially during the corona pandemic, which is caused by most activities carried out from home, requires broadband internet service providers to improve their performance and quality of service. On the other hand, competition among broadband internet service providers is increasing. The wide choice of broadband internet service providers increases the potential for customers to switch (churn). Therefore, companies need to be able to keep their customers. Good and competitive service quality and aspects related to service performance are very important for broadband internet companies to retain and get customers (Quach et al. 2016; Rachmawati, 2020).

Indihome and Firstmedia are two companies providing fixed broadband internet services with national service coverage that compete for the largest market share. Both have similar differentiation elements, emphasizing service quality, and good connectivity for home internet services. Research on the quality of internet service providers has been conducted by previous researchers, namely Thaichon, Lobo, Prentice, \& Quach (2014), Quach et al. (2016), Ulkhaq \& Br. Barus (2017), Joudeh \& Dandis (2018), and Syahnur \& Basalamah (2019). Thaichon et al. (2014) in their research developed a service quality dimension for internet service providers. The research object is residential internet users in Thailand. This study produces a service quality dimension model for internet service providers based on cognitive and affective evaluations of the user. Other relevant research was carried out by Quach et al. (2016) where a study was carried out on the impact of service quality of internet service providers on user behavior. Quach et al. (2016) in their research found that high service quality can prevent customers from making turnover while low or inferior service quality generates complaints and increases customer intention to move.

Research on the object of Indihome as an internet service provider has previously been carried out by Ulkhaq and Br. Barus (2017). Ulkhaq and Br Barus (2017) conducted a study on the analysis of customer satisfaction at Indihome in regional 1 Sumatra using the SERVQUAL dimension. Customer satisfaction analysis is done by measuring the gap between performance and expectation on each dimension indicator. The research shows that there is a negative gap in each dimension. On the other hand, Joudeh and Dandis (2018) in their research evaluated the effect of 
Internet Service Provider service quality on customer loyalty mediated by customer satisfaction. The findings of the study are that good internet service quality will result in customer satisfaction and will increase the level of customer loyalty. Syahnur \& Basalamah (2019) also researched ISP customer satisfaction by measuring the level of Importance and Performance of internet services in Makassar City. This research uses analysis techniques of Importance Performance Analysis (IPA) and Customer Satisfaction Index.

Based on literature studies on previous relevant research that has been previously described, it can be concluded that research on the development of dimensions of ISP service quality (Thaichon et al. 2014; Thaichon et al. 2014), evaluation on the service quality impact of internet service providers on user behavior (Quach et al. 2016), evaluation of ISP customer satisfaction (Syahnur \& Basalamah, 2019; Ulkhaq \& Barus, 2017), and the effect on satisfaction and loyalty (Joudeh \& Dandis, 2018) have previously been conducted. However, research on evaluating service quality at ISPs (fixed broadband) by considering competitor factors is still very limited. The use of ISP-specific quality dimensions (service quality for ISP) is also still very limited. Evaluation of service quality by considering competitor factors is needed to determine the competitiveness position of the service provider company to its competitors. Besides, evaluating service quality based on competitors' service quality can be used as a basis for developing services to face competitors. On the other hand, the fixed broadband service industry is an industry with high competition intensity, so in evaluating service quality, competitor factors need to be taken into account. Therefore, this study was conducted to fill the research gap, namely regarding the quality evaluation of fixed broadband internet services based on ISP dimensions (Network Quality, Customer Service \& Technical Support, Information Quality \& Website Support, Security \& Privacy) by considering competitor factors by using the Importance Performance Competitor Analysis (IPCA) method.

The IPCA method is a method developed to compensate for the shortcomings of the IPA(ImportancePerformance Analysis) method (Albayrak, 2015; Albayrak et al. 2018; DiPietro et al. 2019). In addition, the results of service evaluation using the IPCA method are used as a basis for determining service improvement priorities so that the service can provide performance that is not only in line with customer expectations but is better than its competitors. The objectives of this study are (1) to identify the strengths and weaknesses of Indihome's fixed broadband services using IPA, (2) to determine the competitive position of Indihome relative to First Media based on IPCA mapping, (3) to compare the results of the service quality evaluation of IPA and IPCA.

\section{METHODS}

This research is the result of Telkom University's internal schema research (basic and applied research). This research was conducted for six months, from September 2020 to February 2021. This research began by determining the dimensions of fixed broadband service quality. The determination of dimensions was carried out based on the results of relevant literature studies, namely Service Quality for ISP. Based on the results of the literature study, the dimensions of network quality, customer service \& technical support, Quality \& Website Support, and Security \& Privacy were selected as research variables.

A recapitulation of the literature study which is the basis for determining the research dimensions can be seen in Table 1. Based on the results of the literature study in Table 1, it is known that the variables of network quality, customer service \& technical support, Quality $\&$ Website Support, and Security \& Privacy have been validated in the research of Thaicon et al. (2014) as a quality dimension for internet service providers. In the following year, namely in 2016, this dimension was used in research conducted by Quach et.al (2016). Quach et al. (2016) this study used the dimensions of service quality for internet service providers to determine the impact of quality on customer behavior. Other dimensions such as Tangible, Empathy, Responsiveness, Reliability, Assurance in the research conducted by Ulkhaq (2017) were not used in this study because these five dimensions are dimensions of service quality in general while internet service providers have different characteristics from service characteristics in general. On the other hand, the dimensions used by Joudeh \& Dandis (2018) and Syahnur \& Basalamah (2019) have meanings that intersect with the dimensions of the research conducted by Thaicon et.al (2014), so the dimensions in this study are not used in this research. 
After determining the dimensions (research variables), the next step is to identify the attributes of the fixed broadband service needs for each dimension of the selected Internet Service Provider (ISP).

The service requirement attribute was obtained through the results of a literature study and qualitative methods - interviews with users of fixed broadband (ISP) services. The minimum number of respondents for the qualitative method (interview) is 5 respondents. Approximately 10 respondents have been able to reach saturated level of data (Gentles et al. 2015). In. this research, interviews were conducted with 10 respondents, namely 5 respondents of Indihome customers and 5 respondents of First Media customers. The results of attribute identification on each dimension of fixed broadband services which are then referred to as Internet Service Providers can be seen in Table 2 . Each service quality attribute in Table 2 is then derived into a questionnaire statement item. The questionnaire is divided into 3 parts, namely the first part is a question about the profile of the respondent, the second part is about the assessment of the importance level, and the third is the assessment of the performance level.

The questionnaire that has been designed was then tested for its validity and reliability. Testing the validity of the questionnaire in this study used the item-to-total correlation test (corrected total item correlation). If the value of the item's correlation coefficient to the total or the calculated $\mathrm{r}$-value $>\mathrm{r}$-table with $\mathrm{df}(0.01 ; \mathrm{n}-2)$, then the statement item is said to be valid. The value of the $r$ table used with a sample size of 100 (n) and a confidence level of $95 \%$ is 0.195 . The results of the questionnaire validity test can be seen in Table 3 . The data in Table 3 shows that the value of the $r$ count of all dimensional indicators represented by the questionnaire statement items is greater than the $r$ table $(0.195)$. Therefore, it can be concluded that each item of the questionnaire statement is valid.

Table 1. A recapitulation of literature study on the Service Quality for ISP

\begin{tabular}{|c|c|c|}
\hline Title & Author (Year) & Dimension (Variable) \\
\hline $\begin{array}{l}\text { The development of service quality } \\
\text { dimensions for internet service } \\
\text { providers: Retaining customers of } \\
\text { different usage patterns }\end{array}$ & Thaichon et al. (2014) & $\begin{array}{l}\text { Network Quality, Customer Service \& } \\
\text { Technical Support, Information Quality } \\
\text { \& Website Support, Security \& Privacy }\end{array}$ \\
\hline $\begin{array}{l}\text { An empirical model of home internet } \\
\text { services quality in Thailand }\end{array}$ & Thaichon et al. (2014) & $\begin{array}{l}\text { Network Quality, Customer Service \& } \\
\text { Technical Support, Information Quality } \\
\text { \& Website Support, Security \& Privacy }\end{array}$ \\
\hline $\begin{array}{l}\text { The effects of service quality on } \\
\text { internet service provider customers' } \\
\text { behavior: A mixed-methods study }\end{array}$ & Quach et al. (2016) & $\begin{array}{l}\text { Network Quality, Customer Service \& } \\
\text { Technical Support, Information Quality } \\
\& \text { Website Support, Security \& Privacy }\end{array}$ \\
\hline $\begin{array}{l}\text { Customer Satisfaction Analysis Using } \\
\text { SERVQUAL: Case Study IndiHome } \\
\text { Service PT. Telkom, Tbk }\end{array}$ & Ulkhaq \& Br. Barus (2017) & $\begin{array}{l}\text { Tangible, Empathy, Reliability, } \\
\text { Responsiveness, Assurance }\end{array}$ \\
\hline $\begin{array}{l}\text { Service Quality, Customer Satisfaction } \\
\text { and Loyalty in an Internet Service } \\
\text { Providers }\end{array}$ & Joudeh \& Dandis (2018) & $\begin{array}{l}\text { Internet Service, Price, Employee, } \\
\text { Physical Evidence }\end{array}$ \\
\hline $\begin{array}{l}\text { Analysis of the Importance Degree } \\
\text { and Performance of Internet Service } \\
\text { Providers in Makassar City }\end{array}$ & Syahnur \& Basalamah (2019) & $\begin{array}{l}\text { Customer management, Fulfillment, } \\
\text { Assurance, Billing }\end{array}$ \\
\hline
\end{tabular}


Table 2. Attribute codification recapitulation / questionnaire statement on service quality dimensions for ISP

\begin{tabular}{|c|c|c|c|}
\hline Dimensions & Code & Attribute / Questionnaire Statement & Source \\
\hline \multirow[t]{3}{*}{$\begin{array}{l}\text { Network } \\
\text { Quality }\end{array}$} & NQ1 & ISP provides good internet connectivity speed & $\begin{array}{l}\text { Interview, Quach et al. (2016) } \\
\text { Thaichon et al. (2014) }\end{array}$ \\
\hline & NQ2 & ISP provides good internet connectivity stability & Interview \\
\hline & NQ3 & ISP provides reliable internet quality (* without interruption) & $\begin{array}{l}\text { Interview, Quach et al. (2016) } \\
\text { Thaichon et al. (2014) }\end{array}$ \\
\hline \multirow{6}{*}{$\begin{array}{l}\text { Customer } \\
\text { Service \& } \\
\text { Technical } \\
\text { Support }\end{array}$} & CT1 & ISP technicians use complete uniform attributes & Interview \\
\hline & $\mathrm{CT} 2$ & ISP technicians provide complete installation tools & Interview, Quach et al. (2016) \\
\hline & CT3 & $\begin{array}{l}\text { ISP customer service provides good knowledge of the ISP } \\
\text { product offerings }\end{array}$ & $\begin{array}{l}\text { Interview, Quach et al. (2016) } \\
\text { Thaichon et al. (2014) }\end{array}$ \\
\hline & CT4 & $\begin{array}{l}\text { ISP customer service provides excellent communication skills } \\
\text { when serving customers }\end{array}$ & Interview \\
\hline & CT5 & ISP customer service can serve customer complaints quickly & Interview \\
\hline & CT6 & $\begin{array}{l}\text { ISP Customer Service can resolve disruptions (complaints) } \\
\text { well }\end{array}$ & $\begin{array}{l}\text { Interview, Quach et al. (2016) } \\
\text { Thaichon et al. (2014) }\end{array}$ \\
\hline \multirow{5}{*}{$\begin{array}{l}\text { Information } \\
\text { Quality \& } \\
\text { Website Sup- } \\
\text { port }\end{array}$} & IW1 & ISP provides a compensation policy accordingly. & Interview \\
\hline & IW2 & ISP provides a variety of payment methods. & Interview \\
\hline & IW3 & ISP provides accurate product information & $\begin{array}{l}\text { Interview, Quach et al. (2016) } \\
\text { Thaichon et al. (2014) }\end{array}$ \\
\hline & IW4 & ISP provides a variety of communication channels & Interview \\
\hline & IW5 & ISP provides up-to-date information & $\begin{array}{l}\text { Interview, Quach et al. (2016) } \\
\text { Thaichon et al. (2014) }\end{array}$ \\
\hline \multirow[t]{3}{*}{$\begin{array}{l}\text { Security \& } \\
\text { Privacy }\end{array}$} & SP1 & $\begin{array}{l}\text { ISP can maintain the confidentiality of customers' personal } \\
\text { information }\end{array}$ & $\begin{array}{l}\text { Interview, Quach et al. (2016) } \\
\text { Thaichon et al. (2014) }\end{array}$ \\
\hline & SP2 & ISP can keep customers' financial information confidential & $\begin{array}{l}\text { Quach et al. (2016), Thaichon } \\
\text { et al. (2014) }\end{array}$ \\
\hline & SP3 & ISP provides a secure transaction (payment) system & $\begin{array}{l}\text { Interview, Quach et al. (2016) } \\
\text { Thaichon et al. (2014) }\end{array}$ \\
\hline
\end{tabular}

Table 3. Recapitulation on the results of the questionnaire validity test

\begin{tabular}{lccccc}
\hline \multirow{2}{*}{ Dimensions } & \multirow{2}{*}{ Code Indicator } & \multicolumn{2}{c}{ Interest } & \multicolumn{2}{c}{ Performance } \\
\cline { 3 - 6 } & & The value of r count & Information & The value of r count & Information \\
\hline Network Quality & NQ1 & 0.675 & Valid & 0.314 & Valid \\
& NQ2 & 0.676 & Valid & 0.359 & Valid \\
Customer Service \& & NQ3 & 0.682 & Valid & 0.473 & Valid \\
Technical Support & CT1 & 0.419 & Valid & 0.290 & Valid \\
& CT2 & 0.648 & Valid & 0.354 & Valid \\
& CT3 & 0.611 & Valid & 0.439 & Valid \\
& CT4 & 0.729 & Valid & 0.296 & Valid \\
Information Quality \& & CT5 & 0.648 & Valid & 0.431 & Valid \\
Website Support & CT6 & 0.680 & Valid & 0.470 & Valid \\
& IW1 & 0.697 & Valid & 0.432 & Valid \\
& IW2 & 0.529 & Valid & 0.455 & Valid \\
Security \& Privacy & IW3 & 0.676 & Valid & 0.354 & Valid \\
& IW4 & 0.698 & Valid & 0.507 & Valid \\
& IW5 & 0.552 & Valid & 0.400 & Valid \\
& SP1 & 0.658 & Valid & 0.499 & Valid \\
& SP2 & 0.704 & Valid & 0.469 & Valid \\
& SP3 & 0.485 & Valid & 0.394 & Valid \\
\hline
\end{tabular}


On the other hand, the reliability test in this study used the Cronbach's alpha $(\alpha)$ value. Cronbach's alpha is a coefficient that indicates how well the questionnaire statement items correlate with one another. In this study, the questionnaire statement items were said to be reliable when the Cronbach's Alpha value was $>0.6$ or 1 (Verdian, 2019). The results of the questionnaire reliability test can be seen in Table 4 . Based on the data in Table 4, it is known that each item of the questionnaire statement (dimension indicator) has n Cronbach's Alpha value $>0.6$. All questionnaire statements have a value of $>0.9$ or close to 1 , so it can be said that the item is a reliable questionnaire statement.
Based on the results of the validity and reliability of the questionnaire, it can be concluded that the questionnaire is valid and reliable. After the questionnaire was declared valid and reliable, the questionnaire was then distributed using judgmental sampling techniques. The sample criteria for this study were that respondents were Indihome or Firstmedia users. In this study, Indihome was the focal company while Firstmedia was the competitor company. The questionnaire was distributed online via a google form. The number of samples obtained and processed in this study was 103 respondents of Firstmedia users and 131 respondents of Indihome users, so the total respondents of this study were 234 respondents. The results of the recapitulation of the research respondent profile can be seen in Table 5 .

Table 4. Recapitulation of the questionnaire reliability test results

\begin{tabular}{|c|c|c|c|c|c|}
\hline \multirow{2}{*}{ Dimensions } & \multirow{2}{*}{ Code Indicator } & \multicolumn{2}{|l|}{ Interest } & \multicolumn{2}{|c|}{ Performance } \\
\hline & & The value of $r$ count & Information & The value of $r$ count & Information \\
\hline \multirow[t]{3}{*}{ Network Quality } & NQ1 & 0.917 & Reliable & 0.922 & Reliable \\
\hline & NQ2 & 0.918 & Reliable & 0.921 & Reliable \\
\hline & NQ3 & 0.918 & Reliable & 0.920 & Reliable \\
\hline \multirow{6}{*}{$\begin{array}{l}\text { Customer Service \& } \\
\text { Technical Support }\end{array}$} & CT1 & 0.921 & Reliable & 0.922 & Reliable \\
\hline & $\mathrm{CT} 2$ & 0.918 & Reliable & 0.921 & Reliable \\
\hline & CT3 & 0.918 & Reliable & 0.920 & Reliable \\
\hline & CT4 & 0.916 & Reliable & 0.922 & Reliable \\
\hline & CT5 & 0.918 & Reliable & 0.921 & Reliable \\
\hline & CT6 & 0.917 & Reliable & 0.920 & Reliable \\
\hline \multirow{5}{*}{$\begin{array}{l}\text { Information Quality \& } \\
\text { Website Support }\end{array}$} & IW1 & 0.917 & Reliable & 0.921 & Reliable \\
\hline & IW2 & 0.919 & Reliable & 0.920 & Reliable \\
\hline & IW3 & 0.917 & Reliable & 0.921 & Reliable \\
\hline & IW4 & 0.917 & Reliable & 0.920 & Reliable \\
\hline & IW5 & 0.919 & Reliable & 0.921 & Reliable \\
\hline \multirow[t]{3}{*}{ Security \& Privacy } & SP1 & 0.918 & Reliable & 0.920 & Reliable \\
\hline & SP2 & 0.917 & Reliable & 0.920 & Reliable \\
\hline & SP3 & 0.920 & Reliable & 0.921 & Reliable \\
\hline
\end{tabular}

Table 5. Recapitulation of research respondent profiles

\begin{tabular}{llcr}
\hline Respondent Profile & & Focal Company & Competitor Company \\
& & $\mathrm{N}=131$ & $\mathrm{~N}=103$ \\
\hline Age & $17-24$ years & 111 & 54 \\
& $25-30$ years & 10 & 20 \\
& 31-35 Years & 3 & 12 \\
& $>35$ Years & 7 & 17 \\
Average expenditure per & $<$ Rp 500.000,- & 51 & 19 \\
month & Rp 500.000,- s.d. Rp 1.000.000,- & 45 & 17 \\
& Rp 1.000.001,- s.d. Rp 3.000.000,- & 22 & 36 \\
& Rp 3.000.001,- s.d. Rp 5.000.000,- & 8 & 14 \\
& $>$ Rp 5.000.000,- & 5 & 17 \\
\hline
\end{tabular}


The data obtained is then processed using the IPA (Importance Performance Analysis) method. IPA data processing begins by looking for the average (mean) importance and performance of each ISP quality attribute. The mean data is then mapped in a cartesian science diagram. Based on the mapping of the mean value, each attribute will be mapped into 4 quadrants (Boley et al. 2017; Fausiah et al. 2021; Ho et al. 2016). The next step is to calculate IPCA data by entering competitor performance calculations.

The calculation is done by entering the Performance Difference (PD) value (Santoso et al. 2020), which is the difference between the performance of the focal company and the performance of the competitor company which is mapped on the horizontal axis and uses the focal company Gap (Performance Importance) value on the vertical axis. The attributes will then be mapped into 4 IPCA quadrants (Puspitasari et al. 2019). The research steps previously described are then depicted in the research framework diagram which can be seen in Figure 1.

\section{RESULTS}

\section{Importance Performance Analysis (IPA) Focal Company}

Based on the calculation of the IPA data on the focal company - Indihome in Table 6, it can be seen that almost all indicators have negative Gap values. The positive gap value is the CT1 indicator with a gap value of 0 . A negative gap value indicates a condition where the level of performance is below the level of importance. Besides, a negative gap indicates the respondent's dissatisfaction. The indicator with the largest Gap value is NQ3 which is equal to -0.48. NQ3 is an indicator of the Network Quality dimension with statement items relating to reliable internet quality (uninterrupted). On the other hand, the mean value in terms of performance and importance for all indicators has a value above 3 which falls into the good category. This condition shows that the overall performance is quite good but not enough to satisfy the respondents. The data on average performance and importance are then mapped into the IPA matrix. In Figure 2. it can be seen that there are 5 indicators that fall into the "Concentrate here" quadrant, including CT4, CT6,
NQ1, NQ2, and NQ3. The quadrant of "Keep up the good work" has 6 indicators, namely SP1, SP2, SP3, CT2, CT3, and CT5 while the "Low priority" quadrant has 4 indicators, namely IW1, IW3, IW4, and IW5. There are only 2 dimensional indicators that fall into the "Possible overkill" quadrant, namely CT1 and IW2.

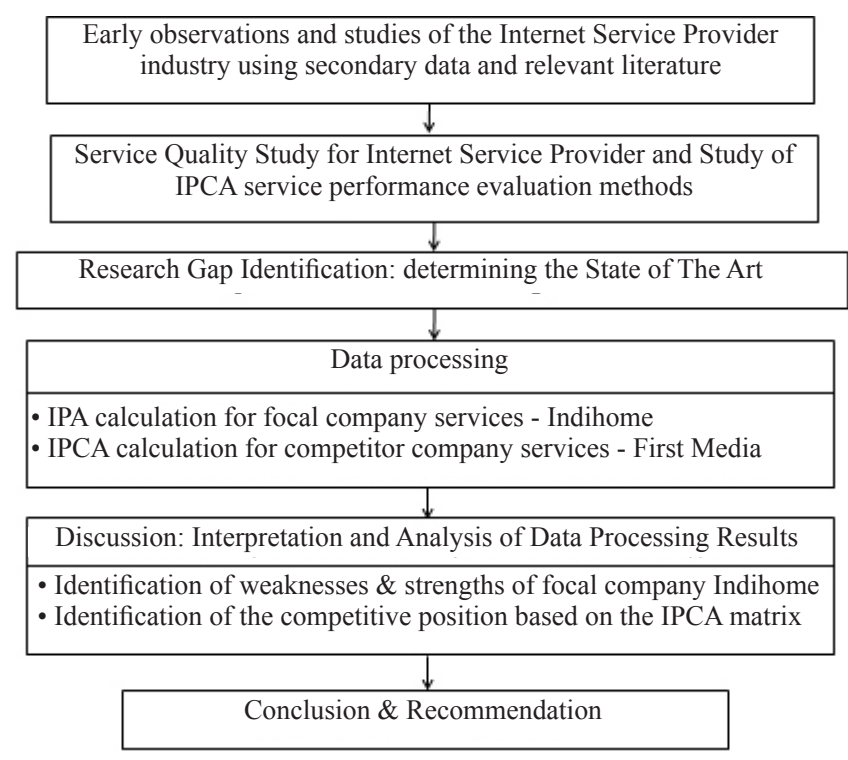

Figure 1. Research framework

Table 6. Data on IPA Focal Company

\begin{tabular}{|c|c|c|c|c|}
\hline \multirow{2}{*}{ Dimensions } & \multirow{2}{*}{ Code } & \multicolumn{2}{|c|}{ Mean } & \multirow{2}{*}{ GAP } \\
\hline & & $P$ & I & \\
\hline \multirow[t]{3}{*}{ Network Quality } & NQ1 & 3.37 & 3.76 & -0.39 \\
\hline & NQ2 & 3.32 & 3.75 & -0.43 \\
\hline & NQ3 & 3.24 & 3.72 & -0.48 \\
\hline \multirow{6}{*}{$\begin{array}{l}\text { Customer Service \& } \\
\text { Technical Support }\end{array}$} & $\mathrm{CT} 1$ & 3.47 & 3.47 & 0.00 \\
\hline & $\mathrm{CT} 2$ & 3.67 & 3.77 & -0.10 \\
\hline & СТ3 & 3.51 & 3.79 & -0.27 \\
\hline & $\mathrm{CT} 4$ & 3.32 & 3.72 & -0.40 \\
\hline & СТ5 & 3.58 & 3.76 & -0.18 \\
\hline & СТ6 & 3.40 & 3.81 & -0.41 \\
\hline \multirow{5}{*}{$\begin{array}{l}\text { Information Quality \& } \\
\text { Website Support }\end{array}$} & IW1 & 3.26 & 3.58 & -0.32 \\
\hline & IW2 & 3.52 & 3.58 & -0.06 \\
\hline & IW3 & 3.40 & 3.66 & -0.27 \\
\hline & IW4 & 3.41 & 3.56 & -0.15 \\
\hline & IW5 & 3.45 & 3.63 & -0.18 \\
\hline \multirow[t]{3}{*}{ Security \& Privacy } & SP1 & 3.58 & 3.87 & -0.29 \\
\hline & SP2 & 3.56 & 3.80 & -0.24 \\
\hline & SP3 & 3.67 & 3.84 & -0.17 \\
\hline
\end{tabular}




\section{Importance Performance Analysis (IPA) Competitor Company}

The results of the calculation of competitor company (Firstmedia) IPA data in Table 7 show that almost all indicators of service quality are negative. However, the competitor company has the largest negative value indicator compared to the focal company, namely CT4 (customer service communication skills in serving customers) with a gap value of -0.65 . The indicator with a positive gap is $\mathrm{CT} 1$ of 0.16 , which is an indicator related to the completeness of the technician's uniform. Overall, the performance score is above 3 , but this value is not sufficient to fulfill the respondent's satisfaction with the importance value which is relatively higher than the performance value. Based on the data in Figure 3 , it can be seen that there are 3 dimensions of service quality indicators that are included in the quadrant of "Concentrate here", including CT4, CT6, and NQ3 while the service quality dimension indicators included in the "Keep up the good work" quadrant have 7 indicators including CT3, CT5, SP1, SP2, SP3, NQ1, and NQ2. On the other hand, there are 4 indicators of service quality dimensions (IW1, IW3, IW4, and IW5) which are included in the "Low priority" quadrant, and 3 indicators of service quality dimensions (CT1, CT2, and IW2) which are included in the "Possible overkill" quadrant.

\section{Importance Performance Competitor Analysis (IPCA) Matrix}

Based on the data in Table 8 regarding the results of IPCA data processing, it is known that there is only 1 indicator that has a negative PD (Performance Difference) value while the other indicators have a positive PD value. This condition shows that overall Indihome (focal) has a better performance than Firstmedia (competitor). The service quality indicator with a negative $\mathrm{PD}$ value is NQ1 (internet connectivity speed) of -0.032 . The results of the mapping of the IPCA focal matrix and the company's competitors can be seen in Figure 3.

Table 7. Data on IPA Competitor Company

\begin{tabular}{lcccc}
\hline \multirow{2}{*}{ Dimensions } & Code & \multicolumn{2}{c}{ Mean } & \multirow{2}{*}{ GAP } \\
\cline { 3 - 4 } Network Quality & NQ1 & 3.40 & 3.79 & -0.39 \\
& NQ2 & 3.30 & 3.86 & -0.56 \\
& NQ3 & 3.18 & 3.81 & -0.62 \\
Customer Service \& & CT1 & 3.29 & 3.14 & 0.16 \\
Technical Support & CT2 & 3.42 & 3.52 & -0.11 \\
& CT3 & 3.36 & 3.69 & -0.33 \\
Information Quality \& & IW1 & 3.14 & 3.50 & -0.36 \\
Website Support & CT5 & 3.13 & 3.78 & -0.65 \\
& IW2 & 3.29 & 3.39 & -0.10 \\
& IW3 & 3.15 & 3.41 & -0.26 \\
& IW4 & 3.23 & 3.36 & -0.13 \\
& IW5 & 3.16 & 3.32 & -0.17 \\
Security \& Privacy & SP1 & 3.35 & 3.69 & -0.34 \\
& SP2 & 3.26 & 3.67 & -0.41 \\
& SP3 & 3.38 & 3.64 & -0.26 \\
\hline & & & &
\end{tabular}

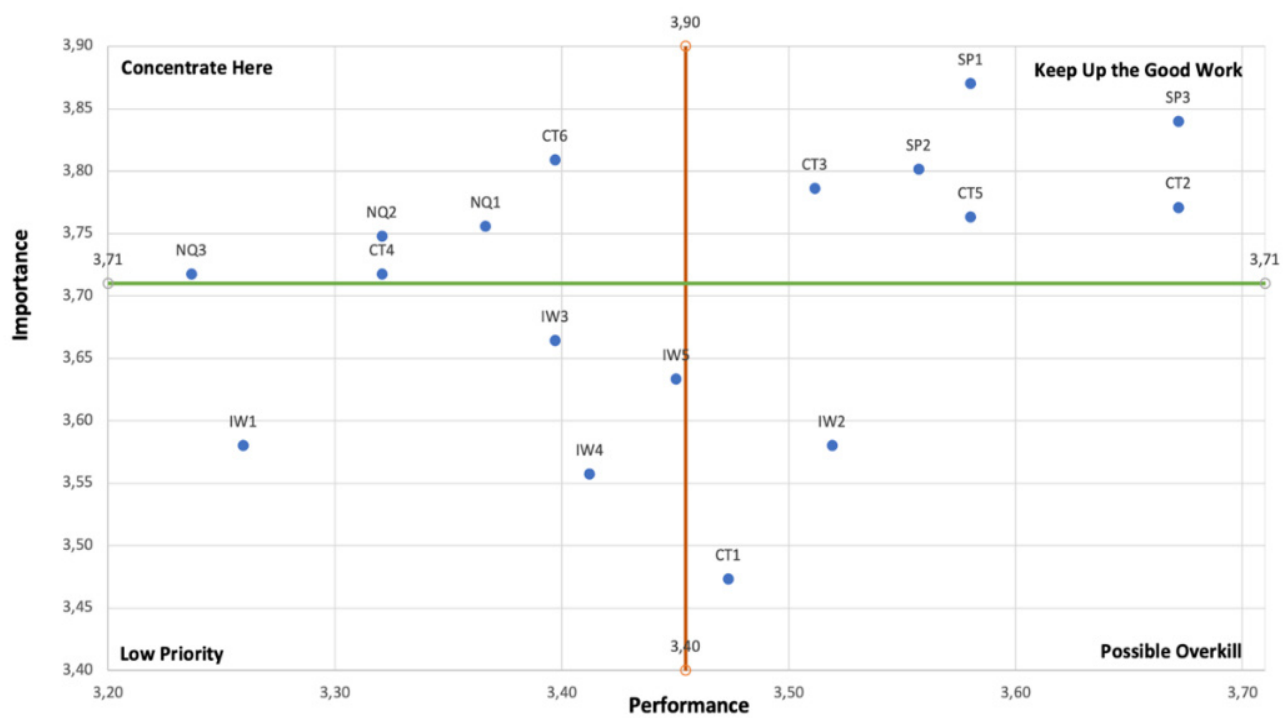

Figure 2. IPA matrix focal company - Indihome 
Table 8. Calculation of IPCA Matrix data

\begin{tabular}{lcccccc}
\hline Code & $\begin{array}{c}\text { Performance } \\
\text { Focal (PF) }\end{array}$ & $\begin{array}{c}\text { Performance } \\
\text { Competitor (PC) }\end{array}$ & GAP & $\begin{array}{c}\text { Importance } \\
\text { Focal (IF) }\end{array}$ & $\begin{array}{c}\text { Importance } \\
\text { Competitor (IC) }\end{array}$ & PD \\
\hline NQ1 & 3.366 & 3.398 & -0.389 & 3.756 & 3.786 & -0.032 \\
NQ2 & 3.321 & 3.301 & -0.427 & 3.748 & 3.864 & 0.020 \\
NQ3 & 3.237 & 3.184 & -0.481 & 3.718 & 3.806 & 0.052 \\
CT1 & 3.473 & 3.291 & 0.000 & 3.473 & 3.136 & 0.182 \\
CT2 & 3.672 & 3.417 & -0.099 & 3.771 & 3.524 & 0.254 \\
CT3 & 3.511 & 3.359 & -0.275 & 3.786 & 3.689 & 0.152 \\
CT4 & 3.321 & 3.126 & -0.397 & 3.718 & 3.777 & 0.194 \\
CT5 & 3.580 & 3.272 & -0.183 & 3.763 & 3.796 & 0.308 \\
CT6 & 3.397 & 3.184 & -0.412 & 3.809 & 3.767 & 0.212 \\
IW1 & 3.260 & 3.136 & -0.321 & 3.580 & 3.495 & 0.124 \\
IW2 & 3.519 & 3.291 & -0.061 & 3.580 & 3.388 & 0.228 \\
IW3 & 3.397 & 3.146 & -0.267 & 3.664 & 3.408 & 0.251 \\
IW4 & 3.412 & 3.233 & -0.145 & 3.557 & 3.359 & 0.179 \\
IW5 & 3.450 & 3.155 & -0.183 & 3.634 & 3.320 & 0.295 \\
SP1 & 3.580 & 3.350 & -0.290 & 3.870 & 3.689 & 0.231 \\
SP2 & 3.557 & 3.262 & -0.244 & 3.802 & 3.670 & 0.295 \\
SP3 & 3.672 & 3.379 & -0.168 & 3.840 & 3.641 & 0.293 \\
\hline
\end{tabular}

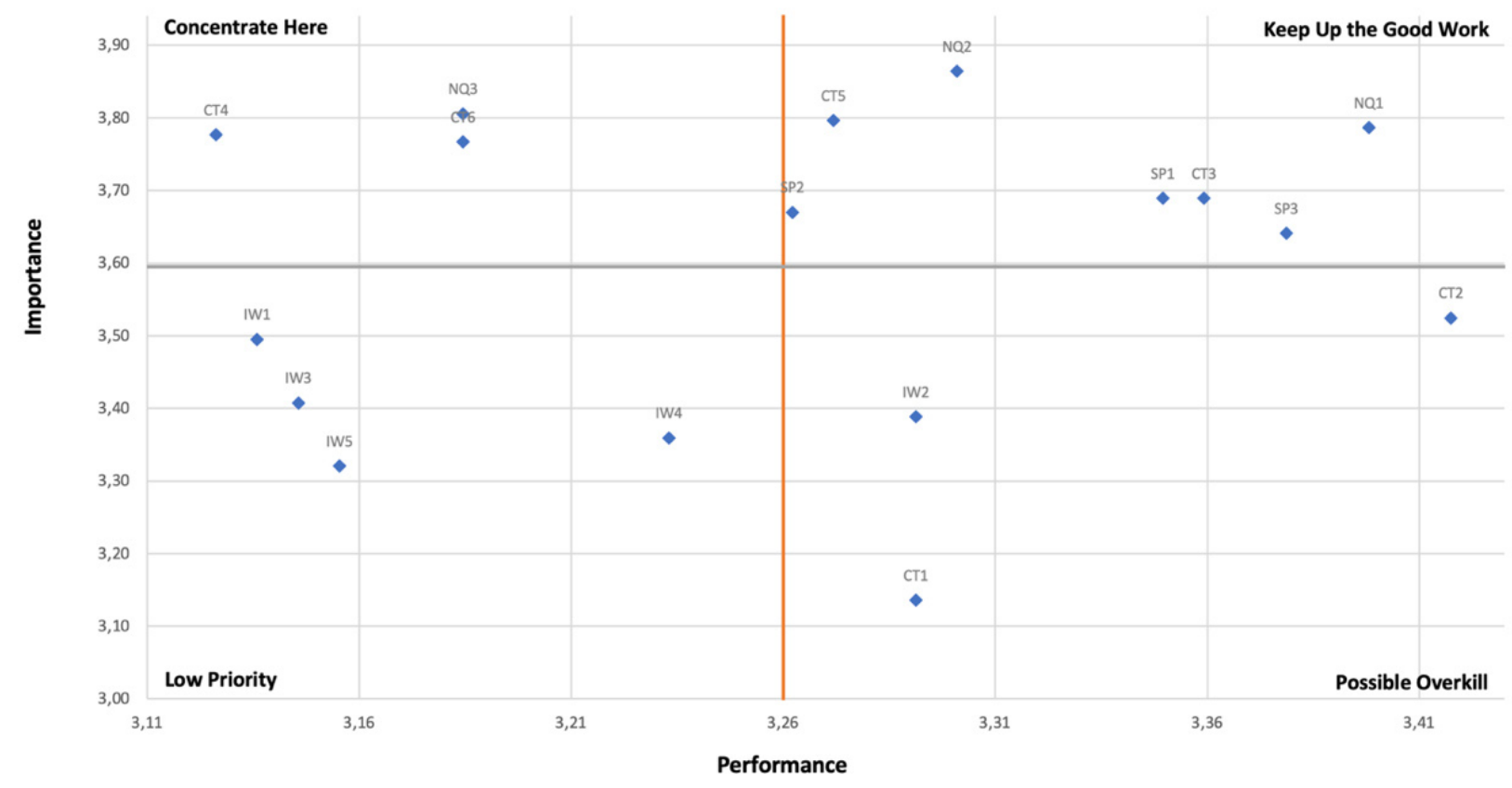

Figure 3. Matrix of IPA competitor company - Firstmedia

Data in Figure 4 and Table 9 show the results of IPCA processing and its comparison to IPA. Based on this data, it can be seen that there are 5 indicators of service quality that are prioritized for improvement to compete with competitors, namely indicators mapped in the "Urgent Action" quadrant. These indicators include NQ1, NQ2, NQ3, CT3, and IW1. The NQ1, NQ2, and NQ3 indicators in the IPA matrix are included in the "Concentrate Here" quadrant. NQ1, NQ2, and NQ3 are indicators of the Network Quality dimension with each indicator representing NQ1 (good internet connectivity speed), NQ2 (good internet connectivity stability), and NQ3 (reliable internet quality). This dimension is classified as critical because the three indicators are basic needs or functions that must be fulfilled by an ISP service. On the other hand, based on IPA and IPCA data, the superiority of the focal company - Indihome which becomes Indihome's competitiveness position 
can be discovered. This indicator is mapped into the "Solid Competitive Advantages" quadrant, which is an indicator with a higher or positive PD value and a higher or positive GAP value. There are 6 indicators mapped into the "Solid Competitive Advantages" quadrant, including CT2, CT5, IW2, IW5, SP2, and SP3. Meanwhile, indicators of service quality dimensions that are included in the "Head-to-head competition" quadrant include CT1 and IW4.

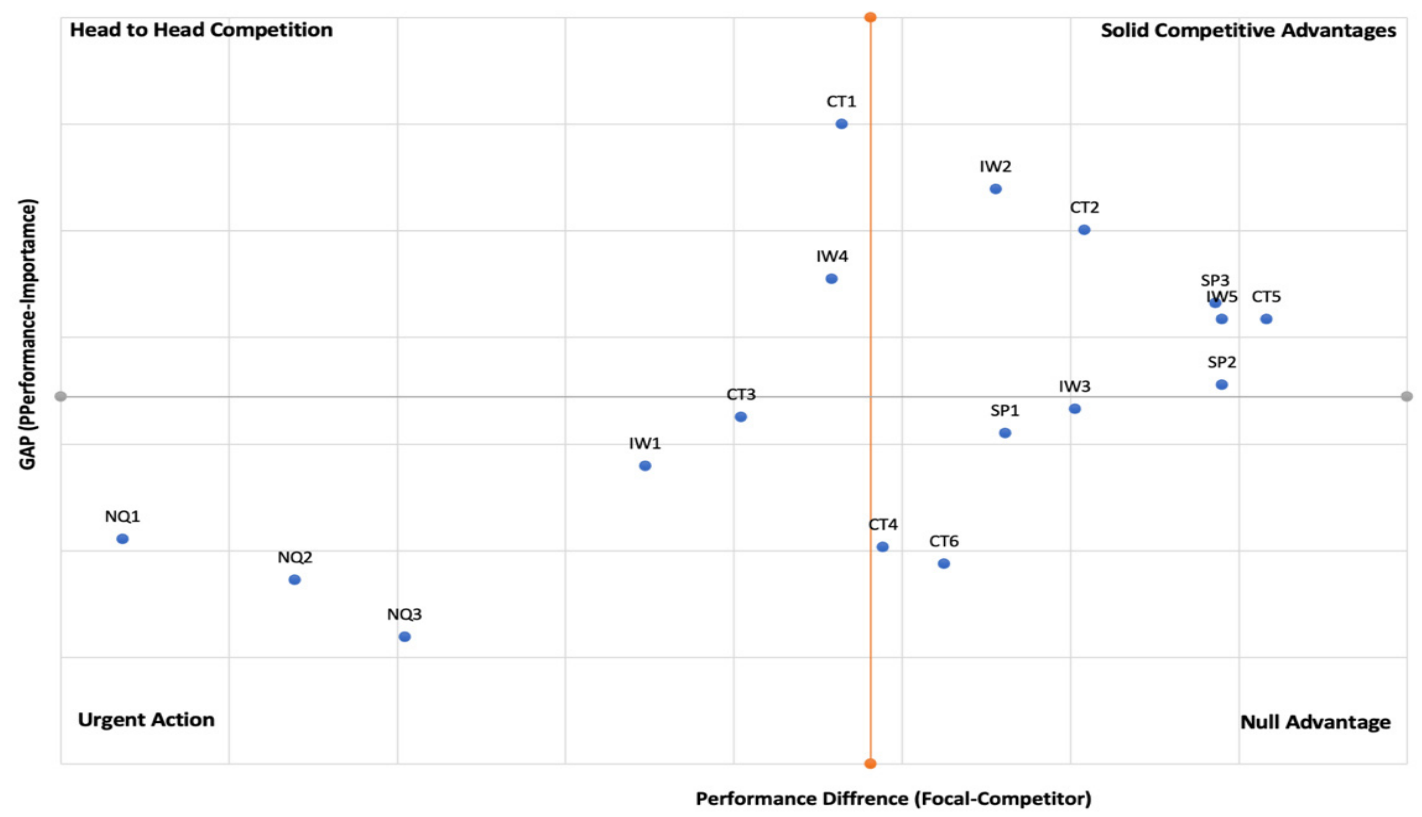

Figure 4. Matrix of IPCA focal company - competitor company

Table 9. Comparison of the IPA and IPCA Matrix

\begin{tabular}{lcccc}
\hline Code & GAP & PD & IPCA QUADRANT & IPA QUADRANT \\
\hline NQ1 & -0.389 & -0.032 & Urgent Action & Concentrate Here \\
NQ2 & -0.427 & 0.020 & Urgent Action & Concentrate Here \\
NQ3 & -0.481 & 0.052 & Urgent Action & Concentrate Here \\
CT1 & 0 & 0.182 & Head-to-Head Competition & Possible Overkill \\
CT2 & -0.099 & 0.254 & Solid Competitive Advantage & Keep Up the Good Work \\
CT3 & -0.275 & 0.152 & Urgent Action & Keep Up the Good Work \\
CT4 & -0.397 & 0.194 & Null Advantage & Concentrate Here \\
CT5 & -0.183 & 0.308 & Solid Competitive Advantage & Keep Up the Good Work \\
CT6 & -0.412 & 0.212 & Null Advantage & Concentrate Here \\
IW1 & -0.321 & 0.124 & Urgent Action & Low Priority \\
IW2 & -0.061 & 0.228 & Solid Competitive Advantage & Possible Overkill \\
IW3 & -0.267 & 0.251 & Null Advantage & Low Priority \\
IW4 & -0.145 & 0.179 & Head-to-Head Competition & Low Priority \\
IW5 & -0.183 & 0.295 & Solid Competitive Advantage & Low Priority \\
SP1 & -0.290 & 0.231 & Null Advantage & Keep Up the Good Work \\
SP2 & -0.244 & 0.295 & Solid Competitive Advantage & Keep Up the Good Work \\
SP3 & -0.168 & 0.293 & Solid Competitive Advantage & Keep Up the Good Work \\
\hline
\end{tabular}


Based on the results of the mapping of IPA Indihome as a focal company and IPA Fisrtmedia as a competitor company, it is known that both of them get a negative GAP score. This shows that the service performance of the two internet service providers has not met customer expectations. This condition is in line with the results of internet quality measurements conducted by Hamdani (2020) that there is a decrease in internet speed. The decline in quality was due to the addition of customers and an increase in internet usage. In the results of the Indihome IPA mapping, it is known that all Network Quality indicators are in the "Concentrate Here" quadrant. The data shows that the quality of the Indihome network needs to be prioritized for improvement. Network Quality is a very important dimension of service quality (Thaichon et al. 2014). Indihome as a leader company should be able to provide the best performance compared to its competitors. Firstmedia as a competitor company shows better performance in terms of Network Quality, especially on indicators NQ1 - good internet connectivity speed, NQ2 - good internet connectivity stability. Another dimension, namely Information Quality \& Website Support, both from Indihome and Firstmedia, generally falls into the Low Priority and Possible overkill categories. Therefore, Indihome and Firstmedia can focus on improving aspects that are considered important for customers. This is partly because the company does not understand the aspects of service that are considered important for customers. Companies can allocate resources to make improvements to aspects that get priority (concentrate here) (Sever, 2015).

IPCA mapping results show that Indihome's competitive advantage is in the indicators CT2 technicians provide complete installation tools, CT5 customer service can serve customer complaints quickly, IW2 - Availability variety of payment methods, IW5 - ISP provides up-to-date information, SP2 - ISP can keep customers' financial information confidential, SP3 - ISP provides a secure transaction (payment) system. In addition, some indicators show that Indihome does not have an advantage over Firstmedia, namely CT4 - ISP customer service provides excellent communication skills when serving customers, CT6 - ISP Customer Service can resolve disruptions (complaints) well, IW3 - ISP provides accurate product information and SP1 - ISP can maintain the confidentiality of customers' personal information. The results of the IPCA mapping can be used as a basis for competitive strategies for companies (Albayrak et al. 2018), namely in the aspects of Customer Service \& Technical Support (CT), Security \& Privacy (SP) and Information Quality $\&$ Website Support.

\section{Managerial Implications}

Based on the results of the IPA and IPCA mapping, here are some managerial implications that are recommended to be carried out including, on the internal aspects of Indihome services, companies need to plan and allocate resources to improve customer service quality and network quality, especially on internet speed to meet increasing internet needs, due to the increasing number of subscribers and internet usage. Meanwhile, in terms of the shortcomings that Indihome has compared to competitors, companies need to prioritize improvements in terms of network quality, customer service and the quality of information available through the company's website.

Based on this information, it can be concluded that Indihome needs to prioritize immediately to improve network quality and customer service by using the latest and most sophisticated devices, increasing network capacity, and improving and paying attention to the ease of users in accessing the company's website and using other channels in an appropriate manner. communicate with current customers. This should also be a continuous improvement so that the company can continue to be competitive and superior to its competitors.

\section{CONCLUSIONS AND RECOMMENDATIONS}

\section{Conclusions}

Based on the objectives and discussion of the research results, it can be concluded that Indihome has weaknesses in 6 indicators, namely all indicators of Network Quality (NQ1, NQ2, NQ3) which are mapped to the "Concentrate Here" - IPA quadrant and with the performance below competitors ("Urgent Action" IPCA), Customer Service \& Technical Support (CT6) which is mapped on quadrant "Concentrate here" - IPA with performance that does not meet customer expectations when compared to competitors ("Null Advantages" IPCA), Customer Service \& Technical Support (CT3) in the category of "Keep up the good work" - IPA with the performance that is still below competitors ("Urgent Action" - IPCA), and Security 
\& Privacy (SP1) which are included in the quadrant "Keep up the good work" - IPA with the performance that has not met customer expectations when compared to competitors ("Null Advantages" - IPCA). The data shows that Indihome has weaknesses from several aspects in the dimensions of Network Quality, Customer Service \& Technical Support and Security \& Privacy. These three dimensions are very important dimensions for creating customer satisfaction (Quach et al. 2016). But on the other hand, Indihome has an advantage in 6 indicators including CT2, CT5, SP2, SP3 which are included in the quadrant "Keep up the good work" - IPA \& "Solid Competitive Advantages" - IPCA, IW4 which are in the category of "Head to head competition" IPCA with the low level of indicator importance for customers ("Low priority" - IPA), and CT1 indicator which is included in the "Head-to-head competition" - IPCA quadrant with the excessive resources or effort given to these indicators ("Possible overkill" - IPA). In addition, from the results of the IPCA matrix, it can be concluded that Indihome's Competitive Position compared to Firstmedia is on indicator (1) CT2, namely the completeness of installation equipment, (2) CT5 which is the speed of Customer Service in serving customer complaints, (3) IW2 which is related to Various payment methods, (4) IW5, namely the availability of up-to-date information, (5) SP2 regarding the confidentiality of customer transaction information, and (6) SP3 regarding the security of the payment transaction system. The advantages possessed based on IPCA mapping can be used as a basis for competitive strategy (Albayrak et al. 2018).

The comparison between the results of IPAand IPCAdata processing shows that there are indicators that perform well when assessed internally, but the performance is not better enough when compared to competitors, namely CT1 (ISP technicians use complete uniform attributes) and IW4 (ISP provides a variety of communication channels). The use of IPCA as an evaluation method is important so that management can find out which aspects of service need to be improved in dealing with competitors. In addition, by using the IPCA method the company can find out the positioning attributes that make the company superior to competitors (Caber, Albayrak, and İsmay1ll1 2017). In this research, the top three competitive position attributes of Indihome are "completeness of installation equipment", "the speed of Customer Service in serving customer complaints", $\&$ "Various payment methods".

\section{Recommendations}

Basedonresearchresults, thesuggestionforthe Indihome company is that Indihome should focus on developing installation services and equipment, handling customer complaints and developing reliable payment processes. In addition, the suggestions for further research include the results of research using IPCA in addition to being compared with IPA as a comparison method. The IPA method as a comparison method can be combined with the Kano Model (IPA - Kano Model). The use of the IPA - Kano Model can provide direction regarding strategic priorities following the level of performance of the evaluation results (Tseng, 2020).

\section{REFERENCES}

Albayrak T. 2015. Importance performance competitor analysis (IPCA): A study of hospitality companies. International Journal of Hospitality Management 48:135-42.

Albayrak T, Meltem C, Rosario MGR, Akın A 2018. Analysis of destination competitiveness by IPA and IPCA Methods: The case of Costa Brava, Spain against Antalya, Turkey. Tourism Management Perspectives 28(June):53-61.

Anggoro B. 2020. Penggunaan internet naik signifikan saat pandemi Covid-19. https://m. mediaindonesia.com/ekonomi/313425/ penggunaan-internet-naik-signifikan-saatpandemi-covid-19).[15 Jun 2020].

Boley BB, McGehee NG, Tom Hammett AL. 2017. Importance-performance analysis (IPA) of sustainable tourism initiatives: The resident perspective. Tourism Management 58:66-77.

Caber M, Albayrak T, İsmayıllı T. 2017. Analysis of congress destinations' competitiveness using importance performance competitor analysis. Journal of Convention and Event Tourism 18(2):100-117.

CNN. 2020. Pengguna internet kala wfh corona meningkat 40 persen di RI. https://www. cnnindonesia.com/teknologi/20200408124947213-491594/pengguna-internet-kala-w fhcorona-meningkat-40-persen-di-ri.[9 May 2020]

Dianawanti V. 2020. riset tunjukkan gaya hidup orang indonesia berubah karena virus Corona Covid-19. https://www.liputan6.com/bola/read/4225707/ riset-tunjukkan-gaya-hidup-orang-indonesiaberubah-karena-virus-corona-covid-19.[13 May 
2020].

DiPietro RB, Jamie AL, Scott T, Thais N. 2019. First-time and repeat tourists' perceptions of authentic Aruban Restaurants: An importanceperformance competitor analysis. Journal of Destination Marketing and Management 14 (November 2018):100366.

Fausiah E, Sarma M, Najib M. 2021. Customer preference and satisfaction level toward organic vegetable attribute (Case study on Top Buah Segar Cibubur). Indonesian Journal of Business and Entrepreneurship (IJBE) 7(1):53-62.

Gentles SJ, Charles C, Ploeg J, McKibbon KA. 2015. Sampling in qualitative research: Insights from an overview of the methods literature. Qualitative Report 20(11):1772-89.

Hamdan LA. 2020. 11 provider internet kabel di Indonesia dan tip memilih yang tepat. https:// id.techinasia.com/inilah-4-provider-internetbroadband-di-indonesia.[23 Jul 2020].

Ho LH, Chang PY, Yen MT. 2016. Using modified IPA to define quality improvement strategies: A study of air-conditioning industry in Taiwan. TQM Journal 28(2):180-94.

Joudeh JMM, Dandis AO. 2018. Service quality, customer satisfaction and loyalty in an internet service providers. International Journal of Business and Management 13(8):108.

Kamaliah A. 2020. operator harus pertahankan layanan internet saat pandemi Corona. https://inet.detik. com/telecommunication/d-4985650/operatorharus-pertahankan-layanan-internet-saatpandemi-corona. [24 Jul 2020].

Puspitasari BN, Pramono SNW, Pertiwi YE. 2019. Kepuasan pelanggan po rosalia indah menggunakan importance performance competitor analysis (IPCA). Jurnal Teknik Industri 14(2):63.

Quach TN, Jebarajakirthy C, Thaichon P. 2016. The effects of service quality on internet service provider customers' behaviour: A mixed methods study. Asia Pacific Journal of Marketing and Logistics 28(3):435-63.

Rachmawati I. 2020. Service quality role on customer's loyalty of indonesia internet service provider during Covid-19. Jurnal Manajemen dan Pemasaran Jasa 13(2):167.

Santoso M, Kusumawati A, Eko IG, Sri P. 2020. Analysis of service quality performance in higher education uses importance performance competitor analysis (IPCA). Indonesian Journal of Social and Humanity Study 23(2):99-104.

Sever I. 2015. Importance-performance analysis: A valid management tool?. Tourism Management 48:43-53.

Syahnur H, Basalamah J. 2019. Analysis of the importance degree and performance of internet service providers in Makassar City. Digital Zone: Jurnal Teknologi Informasi dan Komunikasi 10(2):168-177.

Thaichon P, Lobo A, Prentice C, Quach TN. 2014. The development of service quality dimensions for internet service providers: Retaining customers of different usage patterns. Journal of Retailing and Consumer Services 21(6):1047-1058.

Thaichon P, Lobo A, Mitsis A. 2014. An empirical model of home internet services quality in Thailand. Asia Pacific Journal of Marketing and Logistics 26(2): 190-210.

Tseng CC. 2020. An IPA-Kano model for classifying and diagnosing airport service attributes. Research in Transportation Business and Management 37(March):100499.

Ulkhaq MM, Barus MPB. 2017. Analisis kepuasan pelanggan dengan menggunakan SERVQUAL: StudikasuslayananIndiHomePT.Telekomunikasi Indonesia, Tbk, Regional 1 Sumatera. Jurnal Sistem dan Manajemen Industri 1(2):61.

Verdian E. 2019. Analisis faktor yang merupakan intensi perpindahan merek transportasi online Di Surabaya. Agora 7(1):1-8. 